Research Article

\title{
Knowledge and Attitude of Antibiotic Use among Public in Rural Area of Cempaka, Banjarbaru, South Kalimantan
}

\author{
Nurul Mardiati ${ }^{*}$ \\ Rahmayanti Fitriah 1 \\ Nadia Wahyu Artati 2 \\ Wika Tiarawati ${ }^{1}$ \\ Muhammad Zaini ${ }^{1}$ \\ 1Department of Pharmacy, Sekolah \\ Tinggi Ilmu Kesehatan Borneo Lestari, \\ Banjarbaru, South Kalimantan, \\ Indonesia \\ 2Department of Pharmacy, Universitas \\ Muhammadiyah Surakarta, Surakarta, \\ Central Java, Indonesia \\ *email: nurulmardiati2@gmail.com \\ Keywords: \\ Attitude \\ Antibiotics \\ Antibiotic use \\ Knowledge \\ Public
}

\begin{abstract}
The high intensity of antibiotics relatively uses causes various problems for health, especially bacterial resistance to antibiotics. Lack of public knowledge about the rationale of antibiotics is a factor that can trigger bacterial resistance to antibiotics. This study aims to assess the public's knowledge and attitudes towards antibiotic use in rural areas Cempaka, Banjarbaru, South Kalimantan. This was a descriptive cross-sectional survey method in which closed-ended questionnaires were distributed to 380 rural residents in the village of Cempaka proportional stratified random sampling technique. Data analysis used univariate and bivariate with the Chi-Square statistical test method. In conclusion, the rural residents demonstrated moderate knowledge $(83.2 \%)$ and a positive attitude towards antibiotic use $(97.4 \%)$. There is no significant association between both knowledge level and of antibiotics on the attitude towards antibiotic use.
\end{abstract}

Received: February 15th 2021

Accepted: August 6th, 2021

Published: August 30th, 2021

(c) 2021 Nurul Mardiati, Rahmayanti Fitriah, Nadia Wahyu Artati, Wika Tiarawati, Muhammad Zaini. Published by Institute for Research and Community Services Universitas Muhammadiyah Palangkaraya. This is an Open Access article under the CC-BY-SA License (http://creativecommons.org/licenses/by-sa/4.0/). DOI: https://doi.org/10.33084/ bjop.v4i3.2118

\section{INTRODUCTION}

Antibiotics are the most frequently prescribed, sold, and used drugs around the world ${ }^{1}$. In developing countries, many antibiotics are available without a prescription and cause someone to use antibiotics wisely ${ }^{23}$. Careless use of antibiotics causes the organism to adapt to antibiotics. Furthermore, it causes a decrease in the effectiveness of the antibiotics and resistance, which initially only occurs in hospitals but gradually also in the community ${ }^{4,5}$.

The latest report from the World Health Organization (WHO) in Antimicrobial Resistance: Global Report on Surveillance also shows that Southeast Asia has 64\% of antibiotic use without a prescription and the highest in cases of antibiotic resistance. WHO released data that at least 2,049,442 cases were due to antibiotic resistance, and 23,000 of them died ${ }^{6}$. According to Riset Kesehatan Dasar (Riskesdas, Basic Health Research) 2013 results, 103,850 (35.2\%) of 294,959 households in Indonesia stored drugs for self-medication or self-medication, including antibiotics obtained without a physician's prescription amounting to $86.1 \%$. South Kalimantan Province is the third highest in Indonesia (90.6\%) of households that store antibiotics without a doctor's prescription?

Knowledge and attitudes are social cognitive factors that are interrelated with one another. Based on the results of Kurniawan et al. ${ }^{8}$ study, there was a relationship between 
the level of knowledge about antibiotics and the use of antibiotics without a physician's prescription in Teling Atas Community Health Center, East Indonesia. This is reinforced by Fimanggara et al. ${ }^{9}$, which states that there is an influence of knowledge on the use of antibiotics among College Students in Jatinangor.

Banjarbaru City is one of the areas in South Kalimantan Province, Indonesia. Cempaka is the only rural area in Banjarbaru City ${ }^{10}$. There is no drugstore and pharmacy in the Village of Cempaka. Rural communities usually have low knowledge about medicine and have limited access to health services and medicines ${ }^{11}$. Limited access to health services and medicines, which is generally due to low-income levels, is one of the problems in rural areas. This is further exacerbated by the lack of availability of health personnel and drug information services in primary health facilities so that it has the potential to encourage the practice of antibiotic self-medication ${ }^{12}$.

The limited health facilities available in Cempaka District could be one of the causes of the lack of information about drugs, and this is thought to affect the use of appropriate antibiotics. Pratiwi et al..$^{13}$ reports that knowledge and attitudes influence the rationality of antibiotic use behavior. Therefore, the study aimed to investigate knowledge and the attitude toward using antibiotic use among the public in the Village of Cempaka, Banjarbaru.

\section{MATERIALS AND METHODS}

\section{Materials}

Data collection was carried out using a questionnaire, which was adopted and modified according to the circumstances of the local population from several reports ${ }^{13-17}$. The questionnaire used was a structured questionnaire consisting of an informed consent sheet and the main questionnaire sheet: Part I. Sociodemographic Data of Respondents (gender, age, highest education level, and monthly income); Part II. Antibiotic knowledge (definition of antibiotics, their classification, for example of antibiotics, indications, use, resistance, side effects, and place of purchase); Part III. Attitudes toward Antibiotic Use (attitude of using antibiotics, how to get antibiotics, when to use antibiotics, and antibiotic recommendations to friends or family). The questionnaire could be accessed at http://bit.ly/kuesioner-pengetahuan-sikap-antibiotik

\section{Methods}

This research was a descriptive and observational analytic study by a cross-sectional survey approach. Data collection was performed by using a questionnaire as a research instrument. The independent variable in this study was knowledge of antibiotic use among the public rural Village of Cempaka, while the dependent variable was the attitude toward antibiotic use among the public rural Village of Cempaka.

This research was conducted in the Village of Cempaka (Figure 1), including sub district of Palam, Bangkal, Sungai Tiung, and Cempaka. The research was conducted between January to April 2019. The population in this study was 34,853 people in the Village of Cempaka ${ }^{10}$. The sample in this study was selected randomly using a proportional stratified random sampling technique ${ }^{18}$. The number of samples (380 respondents) was calculated using a formula with an error of $5 \%$ and a confidence level of $95 \%$ - the number of samples calculated based on Formula $\mathbf{1}^{19}$.

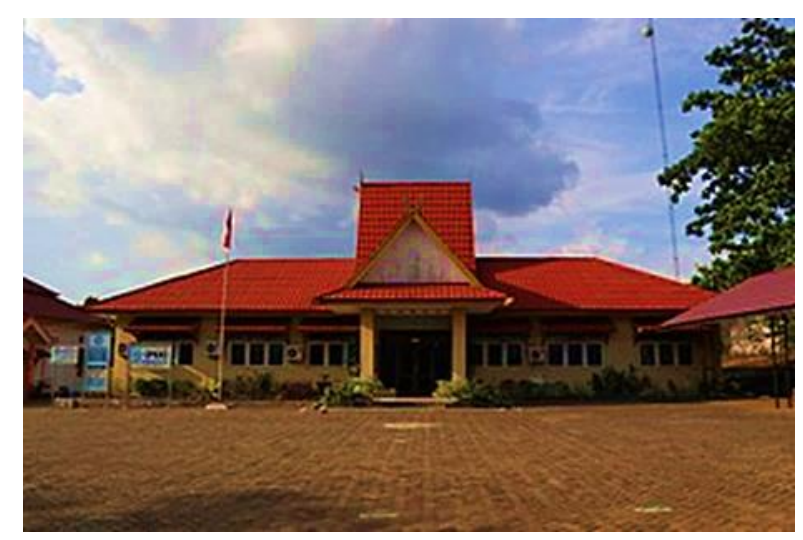

Figure 1. Research location (Cempaka Village) 


$$
n=\frac{N \cdot Z^{2} 1-\frac{\alpha}{2} \cdot p \cdot q}{d^{2}(N-1)+Z^{2} 1-\frac{\alpha}{2} \cdot p \cdot q} \ldots[1]
$$

$\mathrm{n}$ : Samplesize

$\mathrm{N}$ : The sample size of the target population (Palam, Bangkal, Sungai Tiung, and Cempaka)

$\mathrm{p}$ : Estimated proportion (prevalence) of the dependent variable in the population $\mathrm{q}=1-\mathrm{p}$

$Z$ : Z statistic (e.g. $Z=1.96$ for $a=0.05$ )

$\mathrm{d}$ : Delta, the absolute precision or desired margin of error on either side of the proportion

The inclusion criteria in this study included:

1. Permanent residents or residents who have lived for more than six months in the study area

2. Adults $18-65$ years

3. Using antibiotics in the last six months.

While the exclusion criteria in this study included:

1. People who were not willing to be respondents

2. People who experience problems in communication (deaf and mute)

3. People who were sick, so it would be difficult for researchers to communicate

4. Health workers.

The univariate analysis aims to explain or describe the characteristics of each research variable. The form of univariate analysis depends on the type of data. For numerical data, the mean or average, median, and standard deviation are used. In general, this analysis only produces a frequency distribution and percentage of each variable $^{20}$. The level of knowledge and attitude towards antibiotic use is classified according to Widoyoko' ${ }^{21}$, as mentioned in Tables I and II. Bivariate analysis was carried out on two variables thought to be related or correlated. The data interpretation was seen from the significance value. If the significance value obtained was $<0.05$, it could be concluded that variables 1 and 2 have a strong relationship, vice versa ${ }^{20}$.

Table I. Level of knowledge ${ }^{21}$

\begin{tabular}{cc}
\hline Score & Category \\
\hline $15-21$ & Good \\
$8-14$ & Moderate \\
$1-7$ & Poor \\
\hline
\end{tabular}

Table II. Level of attitude towards antibiotic use 21

\begin{tabular}{cc}
\hline Score & Category \\
\hline $23-44$ & Positive \\
$12-22$ & Moderate \\
$0-11$ & Negative \\
\hline
\end{tabular}

\section{RESULTS AND DISCUSSION}

\section{Socio-demographic data of respondents}

Female respondents in this study were 55.5\% (207), more than male respondents with $45.5 \%$ (173). Age characteristics show an age range of 18-40 years with $72.1 \%$ (274), while the age range of $41-65$ years was $27.9 \%$ (106). This shows that more people were on productive age in the Village of Cempaka. The education level shows that the residents of the Village of Cempaka have a low level of education, as evidenced by a large number of people who graduate from primary schools with $51.6 \%$ (196), junior high school graduates with $25.8 \%$ (98), high school graduates with $20.3 \%$ (77), and college/ university graduates with $2.4 \%$ (9). Meanwhile, the characteristics of the monthly income of Village of Cempaka people who earn <South Kalimantan Province Minimum Wage (UMP) in 2019 (Rp. 2,651,781, -) were 85.5\% (326), and those who earn $>$ UMP was $14.5 \%$ (54). Complete data on the characteristics of the respondents were presented in Table III.

Table III. Socio-demographic data of respondents $(n=380)$

\begin{tabular}{lcc}
\hline \multicolumn{1}{c}{ Variables } & $\begin{array}{c}\text { Frequency } \\
\text { (n) }\end{array}$ & $\begin{array}{c}\text { Percentage } \\
\mathbf{( \% )}\end{array}$ \\
\hline Gender & & \\
\hline Male & 173 & 45.5 \\
Female & 207 & 55.5 \\
\hline Age (years old) & & \\
\hline 18-40 & 274 & 72.1 \\
41-65 & 106 & 27.9 \\
\hline Highest education level & & \\
\hline Elementary school & 196 & 51.6 \\
Junior high school & 98 & 25.8 \\
Senior high school & 77 & 20.3 \\
College/University & 9 & 2.4 \\
\hline Monthly income & & \\
\hline < South Kalimantan UMP in & 326 & 85.5 \\
2019 (Rp. 2,651,781, -) & & \\
> South Kalimantan UMP in & 54 & 14.2 \\
2019 (Rp. 2,651,781, -) & & \\
\hline
\end{tabular}




\section{Knowledge of respondents on antibiotics use}

\section{Definition of antibiotics}

Antibiotics fight bacterial infections with a correct answer of $97.1 \%$ (369); this was in line with research conducted by Oh et al. ${ }^{15}$, which reported that respondents understood that antibiotics were used for bacterial infections by $76.7 \%$. It can be concluded that most of the Village of Cempaka residents understand that antibiotics were intended at fighting infections caused by bacteria. However, on the other hand, as many as $80.3 \%$ (350) of the public believe that antibiotics could cure viral infections. This was different from Oh et al..$^{15}$, which reported that respondents were unsure that antibiotics could cure viral infections. These findings might be due to people's ignorance of the difference between bacteria and viruses.

Furthermore, $77.1 \%$ (293) of the public believed that antibiotics could be used for all types of infections. This was supported by direct interviews with the community, with frequent use of antibiotics during fever, flu, cough, and tract infections. Hence, it can be assumed that most people did not fully understand the use of antibiotics; people think that antibiotics could be used to fight all types of infections. The results of this study were consistent with previous studies conducted by $\mathrm{Al}$ Rasheed et al.2, which reported that antibiotics were most often used independently in coughs, sore throats, fevers, and colds. The results of this study indicate that there is irrationality in the use of antibiotics. According to Pavydè et al.23, irrational use of antibiotics reflected a patient's failure to comply with clinical instructions regarding how to use antibiotics and inappropriate antibiotic prescribing. The rational use of antibiotics should be based on the correct indications.

\section{Example of antibiotics}

The sub-dimension of antibiotic drug samples obtained results as much as $95.8 \%$ (364) answered correctly that amoxicillin was an antibiotic drug, so it was concluded that the majority of people know examples of antibiotics. This was following previous research conducted by Fernande $z^{24}$, who reported that most respondents knew that amoxicillin was an example of an antibiotic drug as much as $80.56 \%$. Furthermore, $53.3 \%$ (202) of the public answered correctly that paracetamol was not an example of an antibiotic drug. This was the same as research conducted by Oh et al. ${ }^{15}$, which reported that $66.6 \%$ of respondents thought paracetamol was an antibiotic. This was possible. Because people were free to find antibiotics at the nearest food stall, the same thing as paracetamol which could be purchased at the nearest shop, and the use of antibiotics and paracetamol together when they were not feeling well. As many as 53.9\% (209) of the public answered that the CTM/chlorpheniramine was not an example of an antibiotic. This follows the research by Oh et al. 15 , which reported that respondents disagreed that this allergy drug was included as an antibiotic. It can be concluded that the majority of the knowledge in the Village of Cempaka already knows about examples of antibiotics.

\section{Role of antibiotics}

The results in the sub-dimension of the role of antibiotics show that as many as $77.4 \%$ (294) of the public understand that antibiotics were not used to treat pain and inflammation. This was different from research conducted by Oh et al. 15 , which reported that respondents answered incorrectly that antibiotics were used to treat pain and inflammation. The community misinterprets the role of antibiotics to treat fever as much as $63.4 \%$ (241). This was in line with the research of Al Rasheed et al.22, which reported that people use antibiotics when they have a fever, and the public knows that digestive tract infections use antibiotics as much as $75.8 \%$ (288). This was in line with research by Mouhieddine et al. ${ }^{16}$, which reported that antibiotics (penicillin) were used for 
digestive infections (53.1\%). It can be concluded that the majority of people are well-informed and understand the role of antibiotics.

\section{Administration of antibiotics}

The sub-dimension of antibiotic administration was $56.1 \%$ (213), in which the majority of people did not know that antibiotics should not be taken two tablets at the same time. This was in line with Kim et al. ${ }^{14}$, which reported that respondents believed that the dosage two times the effect was faster. It can be concluded that the irrational use of antibiotics, especially because of inappropriate doses, can lead to resistance to antibiotics in the future. Most people also did not know that antibiotics must be spent even though the condition has recovered from an illness by $61.1 \%$ (232). This is reinforced by $\mathrm{WHO}^{6}$, which reported that from 12 countries, including Indonesia, as many as $53-62 \%$ people stopped taking antibiotics when they felt they were better. This is due to laziness, which the community acknowledges retaking medicine when they feel cured even though the medicine is still left. The majority of people understand that the efficacy of antibiotics would decrease if the antibiotics were not consumed by $62.6 \%$ (234). This was in line with a study conducted by Mouhieddine et al. ${ }^{16}$, with $59 \%$ of people knowing that the efficacy of antibiotics would decrease if not spent.

\section{Antibiotics resistance}

The results in the sub-dimensions of knowledge about antibiotic resistance were $62.6 \%$ (238). Most people know that if antibiotics were not used up, the bacteria would be resistant to antibiotics. This was different from research conducted by Kim et al. ${ }^{14}$, which reported that only $42.5 \%$ of respondents know that bacteria would be resistant if the antibiotic were less than the prescribed dose. Most people did not know that if antibiotics were used less than the specified dose, it would cause bacteria resistance to antibiotics by $37.4 \%$ (144). This was in line with Kim et al. ${ }^{14}$, which reported that respondents knew as much as $42.5 \%$ the use of antibiotics less than the prescribed dose would cause the bacteria to become resistant to antibiotics. The majority of people know that excessive use of antibiotics would cause bacteria to be resistant to this antibiotic $58.4 \%$ (222). This is confirmed by Mouhieddine et al.16, which reported that people know that excessive use of antibiotics could cause bacteria to be resistant to antibiotics.

\section{Adverse effects of antibiotics}

The results in the sub-dimensions of knowledge about the side effects of antibiotics, $62.6 \%$ (238) of the public know that a person could experience allergies to antibiotics. This is in line with Mouhieddine et al. ${ }^{16}$, which reported that $66.7 \%$ of respondents know that a person can experience an antibiotic allergy. Most people did not know that antibiotics have side effects of $52.1 \%$ (198). This is in contrast to research conducted by Kim et al. ${ }^{14}$, which reported that respondents know that $70.5 \%$ of antibiotics have side effects, with the results of interviews conducted reporting that they did not feel any side effects from the antibiotics they were taking. The community knew that nausea and vomiting were among the adverse effects of the antibiotics by $55.8 \%$ (212). It can be concluded that the sub-dimension of knowledge on the side effects of antibiotics in the Village of Cempaka community is quite good.

\section{Place of antibiotics purchase}

The results in the sub-dimensions of knowledge about the place of antibiotics purchase, the majority of people know that antibiotics could only be purchased at pharmacies by $53.4 \%$ (203). In comparison, only $15 \%$ (57) of the public knew that antibiotics could not be purchased at drugstores. Lastly, 23.9\% (91) of the public knew that antibiotics could not be purchased at the shop. The complete results of this section were presented in Table IV. 
Table IV. Knowledge of respondents on antibiotics use

\begin{tabular}{|c|c|c|}
\hline Statements & $\begin{array}{l}\text { Correct } \\
\text { n }(\%)\end{array}$ & $\begin{array}{c}\text { Incorrect } \\
\text { n (\%) }\end{array}$ \\
\hline \multicolumn{3}{|l|}{ Definition of antibiotics } \\
\hline $\begin{array}{l}\text { Antibiotics work to fight } \\
\text { infection bacteria }\end{array}$ & $369(97.1)$ & $11(2.9)$ \\
\hline $\begin{array}{l}\text { 2. Antibiotics are drugs that } \\
\text { can treat infections } \\
\text { because of a virus }\end{array}$ & $350(80.3)$ & 75 (19.7) \\
\hline $\begin{array}{l}\text { 3. Antibiotics can cure all } \\
\text { kinds of infections }\end{array}$ & $293(77.1)$ & $87(22.9)$ \\
\hline \multicolumn{3}{|l|}{ Example of antibiotics } \\
\hline 4. Amoxicillin is an antibiotic & $364(95.8)$ & $16(4.2)$ \\
\hline $\begin{array}{l}\text { 5. Paracetamol is an } \\
\text { antibiotic }\end{array}$ & $202(53.2)$ & $178(46.8)$ \\
\hline 6. CTM is not an antibiotic & $205(53.9)$ & $175(46.1)$ \\
\hline \multicolumn{3}{|l|}{ Role of antibiotics } \\
\hline $\begin{array}{l}\text { 7. Antibiotics can be used to } \\
\text { treat taste pain and } \\
\text { inflammation }\end{array}$ & $294(77.4)$ & $86(22.6)$ \\
\hline $\begin{array}{l}\text { 8. Antibiotics can be used for } \\
\text { treat fever }\end{array}$ & $136(36.6)$ & $241(63.4)$ \\
\hline $\begin{array}{l}\text { 9. Antibiotics can be used to } \\
\text { treat infections digestive } \\
\text { tract }\end{array}$ & $288(75.8)$ & $92(24.4)$ \\
\hline \multicolumn{3}{|l|}{ Administration of antibiotics } \\
\hline $\begin{array}{l}\text { 10. If you take } 2 \text { tablets of } \\
\text { antibiotics in one take, the } \\
\text { drug will be work faster }\end{array}$ & $213(56.1)$ & $197(43.9)$ \\
\hline $\begin{array}{l}\text { 11. You can stop using } \\
\text { antibiotics when you get } \\
\text { better, even if it's } \\
\text { antibiotics has not been } \\
\text { exhausted }\end{array}$ & $232(61.1)$ & $148(38.9)$ \\
\hline $\begin{array}{l}\text { 12. Antibiotics efficacy will } \\
\text { decrease if antibiotics are } \\
\text { not spent }\end{array}$ & $234(61.6)$ & $136(38.4)$ \\
\hline \multicolumn{3}{|l|}{ Antibiotics resistance } \\
\hline $\begin{array}{l}\text { 13. If the use of antibiotics is } \\
\text { not spent, the bacteria will } \\
\text { become resistant to it } \\
\text { antibiotics }\end{array}$ & $238(62.6)$ & $142(37.4)$ \\
\hline $\begin{array}{l}\text { 14. The use of antibiotics less } \\
\text { than the prescribed dose } \\
\text { will cause bacteria are not } \\
\text { resistant to antibiotics }\end{array}$ & $236(62.1)$ & $144(37.9)$ \\
\hline 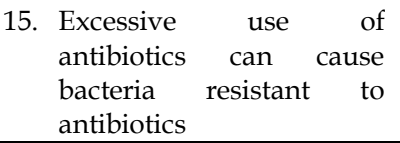 & $222(58.4)$ & $158(41.6)$ \\
\hline \multicolumn{3}{|l|}{ Adverse effects of antibiotics } \\
\hline $\begin{array}{l}\text { 16. A person can experience } \\
\text { allergies when using } \\
\text { antibiotics }\end{array}$ & $238(62.6)$ & $142(37.4)$ \\
\hline $\begin{array}{l}\text { 17. Antibiotics have no effect } \\
\text { side }\end{array}$ & $198(52.1)$ & $182(47.9)$ \\
\hline $\begin{array}{l}\text { 18. Nausea and vomiting are } \\
\text { side effects of antibiotics }\end{array}$ & $212(55.8)$ & $168(44.2)$ \\
\hline \multicolumn{3}{|l|}{ Place of antibiotics purchase } \\
\hline $\begin{array}{l}\text { 19. Antibiotics can only be } \\
\text { purchased at the } \\
\text { pharmacy }\end{array}$ & $203(53.4)$ & $177(46.6)$ \\
\hline $\begin{array}{l}\text { 20. Antibiotics can purchased } \\
\text { at the Drugstore }\end{array}$ & $323(85)$ & $57(15)$ \\
\hline $\begin{array}{l}\text { 21. Antibiotics can be } \\
\text { purchased at the shop }\end{array}$ & $289(76.1)$ & $91(23.9)$ \\
\hline
\end{tabular}

\section{Attitude of respondents towards antibiotics use}

Attitude towards antibiotics use

The data shows that $35.8 \%$ of respondents (136) did not agree that they expect the physician to prescribe antibiotics if they had a headache. This proves that the public understands that there was no need for antibiotics for headaches, and as much as 51.8\% (162) disagreed with taking antibiotics if you felt unwell. This is in line with Oh et al. ${ }^{15}$, who reported that $53.3 \%$ of respondents did not agree to take antibiotics when they felt unwell; this shows that people have understood that there is no need to take antibiotics when they are not feeling well.

The majority of the community, 59.7\% (227), agree that they would see the expiration date before taking antibiotics. This is the same as research by Oh et al. ${ }^{15}$, which reported that $92.2 \%$ of respondents agreed to see an expired label on the package before taking antibiotics. This confirms that the community is careful before taking antibiotics.The majority of people did not agree that if they catch the flu, they take antibiotics to get better quickly, as much as $26.1 \%$ (99). This is in line with research from Kim et al. ${ }^{14}$, which reported that respondents disagreed with the use of antibiotics when exposed to flu so that they quickly get well. People already understand that antibiotics cannot speed up the recovery of a person with flu.

Most people did not agree to keep antibiotic stocks at home for emergencies by $57.1 \%$ (217). They agreed that taking antibiotics should be done according to the instructions on the packaging label. Previous research ${ }^{15}$ reported that $80.1 \%$ of respondents disagreed with antibiotics being kept for emergencies. This is true because antibiotics must be consumed within a predetermined time ${ }^{25}$. Most people agree that taking antibiotics must see the label instructions on the drug packaging by $73.9 \%$ (281). This was in line with previous research $^{15}$, which reported that respondents took 
antibiotics following the instructions from the drug packaging label by $98.1 \%$ by looking at packaging labels to minimize errors when taking antibiotics.

\section{Source of antibiotics}

The data shows that respondents agreed to choose antibiotics prescribed by physicians rather than nurses, with $69.5 \%$ (264). Antibiotics must be obtained using a doctor's prescription because inappropriate use of antibiotics can cause resistance. His research also states that only $32 \%$ use prescriptions to get antibiotics. This suggests that most of the Village of Cempaka community understands that antibiotics could only be prescribed by physicians rather than nurses. As much as $40.8 \%$ (155) of respondents disagree with media statements that the internet helps determine the right antibiotic. This shows that respondents understand that the internet should not be used to determine the right antibiotic.

\section{Antibiotics recommendations for colleagues and family}

As many as $66.6 \%$ (253) of respondents disagree with giving antibiotics to sick families. This illustrates that respondents understood that there was no need to give antibiotics to families who were sick. As many as 58.4\% (222) of respondents answered that they agree not to give antibiotics to sick friends. This illustrates that respondents understand that antibiotics did not need to be recommended to friends who were sick. As much as $57.6 \%$ (219) of respondents answered that they did not agree to give antibiotics to sick neighbors. This illustrates that respondents understand that antibiotics did not need to be handed over to sick neighbors. This is in line with a study conducted by Oh et al. ${ }^{15}$, which reported that as many as $88.2 \%$ did not agree to give antibiotics when their family was sick. This is appropriate because antibiotics can only be purchased at pharmacies with a doctor's prescription. The complete results of this section were presented in Table V.
Table V. Attitude of respondents towards antibiotics use

\begin{tabular}{|c|c|c|c|c|c|}
\hline & Statements & $\begin{array}{c}\text { Strongly } \\
\text { Disagree } \\
\text { n (\%) } \\
\end{array}$ & $\begin{array}{c}\text { Disagr } \\
\text { ee } \\
n(\%) \\
\end{array}$ & $\begin{array}{c}\text { Agree } \\
\text { n ( } \%)\end{array}$ & $\begin{array}{c}\text { Strongly } \\
\text { Disagree } \\
\text { n (\%) } \\
\end{array}$ \\
\hline \multicolumn{6}{|c|}{ Attitude towards antibiotics use } \\
\hline 1. & $\begin{array}{l}\text { When I have a } \\
\text { headache, I } \\
\text { expect the } \\
\begin{array}{l}\text { doctor to } \\
\text { prescribe } \\
\text { antibiotics }\end{array}\end{array}$ & $8(2.1)$ & $\begin{array}{c}136 \\
(35.8)\end{array}$ & $\begin{array}{c}211 \\
(55.5)\end{array}$ & $25(6.6)$ \\
\hline 2. & $\begin{array}{l}\text { I will take } \\
\text { antibiotics } \\
\text { when I don't } \\
\text { feel well }\end{array}$ & $12(3.2)$ & $\begin{array}{c}162 \\
(51.8)\end{array}$ & $\begin{array}{c}197 \\
(51.8)\end{array}$ & $12(3.2)$ \\
\hline 3. & $\begin{array}{l}\text { Before taking } \\
\text { antibiotics, I } \\
\text { will check } \\
\text { their } \\
\text { expiration } \\
\text { date }\end{array}$ & $5(1.3)$ & $30(7.9)$ & $\begin{array}{c}227 \\
(59.7)\end{array}$ & $\begin{array}{c}118 \\
(31.1)\end{array}$ \\
\hline 4. & $\begin{array}{l}\text { I keep a stock } \\
\text { of antibiotics } \\
\text { at home for } \\
\text { emergencies }\end{array}$ & $6(1.6)$ & $\begin{array}{c}160 \\
(42.1)\end{array}$ & $\begin{array}{c}217 \\
(48.2)\end{array}$ & $31(8.2)$ \\
\hline 5. & $\begin{array}{l}\text { When I } \\
\text { caught a cold I } \\
\text { would take } \\
\text { antibiotics to } \\
\text { get better } \\
\text { soon }\end{array}$ & $14(3.7)$ & $\begin{array}{c}99 \\
(26.1)\end{array}$ & $\begin{array}{c}217 \\
(57.1)\end{array}$ & $50(13.2)$ \\
\hline & $\begin{array}{l}\text { I took } \\
\text { antibiotics } \\
\text { according to } \\
\text { the directions } \\
\text { on the } \\
\text { medicine } \\
\text { package label }\end{array}$ & $4(1.1)$ & $37(9.7)$ & $\begin{array}{c}281 \\
(73.9)\end{array}$ & $58(15.3)$ \\
\hline \multicolumn{6}{|c|}{ Source of antibiotics } \\
\hline & $\begin{array}{l}\text { I would prefer } \\
\text { an antibiotic } \\
\text { prescribed by a } \\
\text { doctor over a } \\
\text { nurse }\end{array}$ & $5(1.3)$ & $\begin{array}{c}43 \\
(11.3)\end{array}$ & $\begin{array}{c}264 \\
(69.5)\end{array}$ & $68(17.9)$ \\
\hline & $\begin{array}{l}\text { I believe the } \\
\text { internet is } \\
\text { helpful in } \\
\text { determini-ng } \\
\text { the right } \\
\text { antibiotic }\end{array}$ & $14(3.7)$ & $\begin{array}{c}155 \\
(40.8)\end{array}$ & $\begin{array}{c}191 \\
(50.3)\end{array}$ & $20(5.3)$ \\
\hline \multicolumn{6}{|c|}{ Antibiotics recommendations to colleagues and family } \\
\hline & $\begin{array}{l}\text { I will suggest } \\
\text { antibiotics to } \\
\text { my family who } \\
\text { are sick }\end{array}$ & $29(7.6)$ & $\begin{array}{c}253 \\
(66.6)\end{array}$ & $\begin{array}{c}92 \\
(24.2)\end{array}$ & $6(1.6)$ \\
\hline & $\begin{array}{l}\text { I am not going } \\
\text { to suggest } \\
\text { antibiotics to } \\
\text { my friend who } \\
\text { is sick }\end{array}$ & $8(2.1)$ & $\begin{array}{c}125 \\
(32.9)\end{array}$ & $\begin{array}{c}222 \\
(58.4)\end{array}$ & $25(6.6)$ \\
\hline & $\begin{array}{l}\text { I will suggest } \\
\text { antibiotics to } \\
\text { my neighbor } \\
\text { who is sick }\end{array}$ & $25(6.6)$ & $\begin{array}{c}219 \\
(57.6)\end{array}$ & $\begin{array}{c}125 \\
(32.9)\end{array}$ & $11(2.9)$ \\
\hline
\end{tabular}

The results of the questionnaire assessment regarding the level of knowledge of the Village of Cempaka community in this study was included in the moderate category with $83.2 \%$ (316) of respondents. The results of the questionnaire assessment were divided into three categories concerning the attitude of using antibiotics, viz 
positive, moderate, and negative. Most residents had positive attitudes toward antibiotic use, with $97.4 \%$ (370). This was the same as research conducted by Pratiwi et al..$^{13}$ in the people of the village of East Lampung district, which reported that $60 \%$ of people's attitudes towards antibiotics were in a positive category. Complete results were presented in Figures 2 and 3.

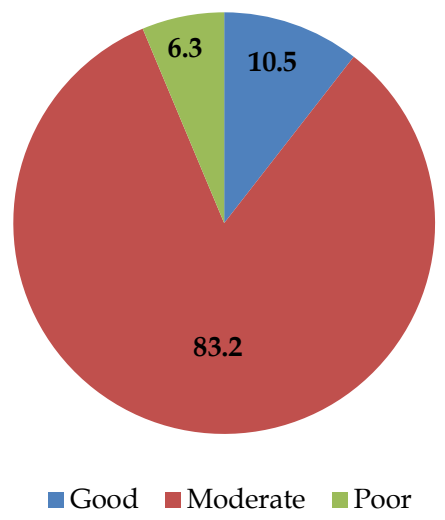

Figure 2. Level of knowledge towards antibiotics use at the Village of Cempaka

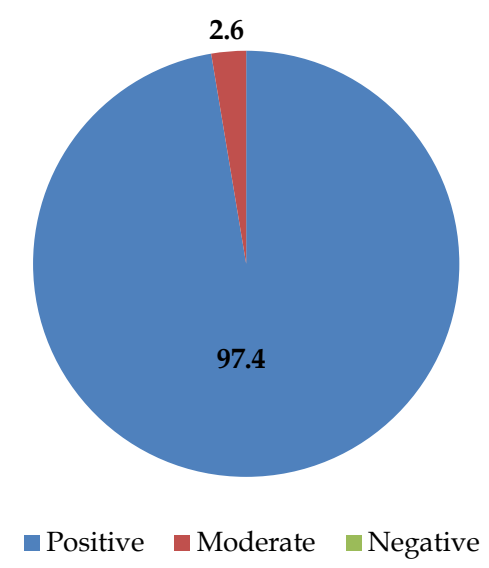

Figure 3. Level of attitude towards antibiotics use at the Village of Cempaka

\section{Association between the level of knowledge and attitude towards antibiotics use}

The analysis of the association between the level of knowledge and attitude towards antibiotics was used by bivariate analysis. It was known that there were 33.3\% that had an expected frequency of less than 5 , so the chisquare test could not be used; instead, the Kruskal-Wallis test was used by looking at the significant value on the test statistics. The asymp sig was 0.216 ; this value is $>0.05$, which means there was no significant association between knowledge and attitude towards antibiotics use among the public in the Village of Cempaka. Attitudes are influenced by several factors, including personal experience, which must leave an impression ${ }^{26}$.

\section{CONCLUSION}

The majority of the knowledge of antibiotics in the Village of Cempaka has a moderate level of knowledge, $83.2 \%$. It is recommended for appropriate authorities to conduct strategic planning to enhance proper antibiotic use by targeting rural areas besides the general public in cities or suburban areas. Although the attitude towards antibiotic use in the Village of Cempaka has a positive level of $97.4 \%$. There is no significant association between both knowledges of antibiotics and attitude towards antibiotic use in the Village of Cempaka.

\section{ACKNOWLEDGMENT}

The authors would like to thank Kementerian Riset dan Teknologi Republik Indonesia/BRIN for funding this research.

\section{AUTHORS' CONTRIBUTION}

Nurul Mardiati: conceived and design the analysis, writing of the paper. Rahmayanti Fitriah: conceived and design the analysis. Nadia Wahyu Artati: collected data, contributed data or analysis tools. Wika Tiarawati: collected data, contributed data or analysis tools. Muhammad Zaini: collected data, contributed data or analysis tools.

\section{DATA AVAILABILITY}

None. 


\section{CONFLICT OF INTEREST}

The authors declare no conflict of interest.

\section{REFERENCES}

1. Ventola CL. The Antibiotic Resistance Crisis. Part 1: Causes and Threats. P T. 2015;40(4):277-83

2. Ayukekbong JA, Ntemgwa M, Atabe AN. The threat of antimicrobial resistance in developing countries: causes and control strategies. Antimicrob Resist Infect Control. 2017;6:47. doi:10.1186/s13756-017-0208-x

3. Nepal G, BhattaS. Self-medication with Antibiotics in WHOSoutheast Asian Region: A Systematic Review. Cureus. 2018;10(4):e2428. doi:10.7759/cureus.2428

4. Munita JM, Arias CA. Mechanisms of Antibiotic Resistance. Microbiol Spectr. 2016;4(2):0016-2015. doi:10.1128/microbiolspec.vmbf-0016-2015

5. Manyi-Loh C, Mamphweli S, Meyer E, Okoh A. Antibiotic Use in Agriculture and Its Consequential Resistance in Environmental Sources: Potential Public Health Implications. Molecules. 2018;23(4):795. doi:10.3390/molecules23040795

6. World Health Organization. Antimicrobial resistance in the South-East Asia [Internet]. Geneva: World Health Organization; 2014. Available from: https://www.who.int/southeastasia/healthtopics/antimicrobial-resistance

7. Ministry of Health Republic of Indonesia. Hasil Utama Riskesdas 2013. Jakarta: Health Research and Development Agency, Ministry of Health Republic of Indonesia; 2013.

8. Kurniawan K, Posangi J, Rampengan N. Association between public knowledge regarding antibiotics and self-medication with antibiotics in Teling Atas Community Health Center, East Indonesia. Med J Indones. 2017;26(1):62-9. doi:10.13181/mij.v26i1.1589

9. Fimanggara B, Istriati I, Diposarosa R. Knowledge and Attitude towards Antibiotic Use among College Students in Jatinangor. Althea Med J. 2016;3(2):26974. doi:10.15850/amj.v3n2.792

10. Central Bureau of Statistics of the Republic of Indonesia. Klasifikasi Perkotaan dan Perdesaan di Indonesia. Jakarta: Central Bureau of Statistics of the Republic of Indonesia; 2010
11. Loftus J, Allen EM, Call KT, Everson-Rose SA. RuralUrban Differences in Access to Preventive Health Care Among Publicly Insured Minnesotans. J Rural Health. 2018;34(Suppl 1):s48-s55. doi:10.1111/jrh.12235

12. Haque M, Rahman NAA, McKimm J, Kibria GM, Majumder MAA, Haque SZ, et al. Self-medication of antibiotics: investigating practice among university students at the Malaysian National Defence University. Infect Drug Resist. 2019;12:1333-51. doi:10.2147/idr.s203364

13. Pratiwi RI, Rustamadji R, Widayati A. Pengetahuan Mengenai Antibiotika Di Kalangan Mahasiswa Ilmu Ilmu Kesehatan Universitas Gadjah Mada Yogyakarta. Jurnal Farmasi Sains dan Komunitas Journal of Pharmaceutical Sciences and Community. 2013;10(2):61-70. doi:10.24071/jpsc.0091

14. Kim SS, Moon S, Kim EJ. Public knowledge and attitudes regarding antibiotic use in South Korea. J Korean Acad Nurs. 2011;41(6):742-9. doi:10.4040/jkan.2011.41.6.742

15. Oh AL, Hassali MA, Al-Haddad MS, Sulaiman SAS, Shafie AA, Awaisu A. Public knowledge and attitudes towards antibiotic usage: a cross-sectional study among the general public in the state of Penang, Malaysia. J Infect Dev Ctries. 2011;5(5):33847. doi:10.3855/jidc.1502

16. Mouhieddine TH, Olleik Z, Itani MM, Kawtharani S, Nassar H, Hassoun R, et al. Assessing the Lebanese population for their knowledge, attitudes and practices of antibiotic usage. J Infect Public Health. 2015;8(1):20-31. doi:10.1016/j.jiph.2014.07.010

17. Widayati A, Suryawati S, de Crespigny C, Hiller JE. Knowledge and beliefs about antibiotics among people in Yogyakarta City Indonesia: a cross sectional population-based survey. Antimicrob Resist Infect Control. 2012;1:38. doi:10.1186/2047-2994-1-38

18. Sugiyono. Metode Penelitian Kuantitatif, Kualitatif dan R\&D. Bandung: Alfabeta; 2008

19. Murti B. Desain danUkuran Sampel untukPenelitian Kuantitatif dan Kualitatif di Bidang Kesehatan. Yogyakarta: Gadjah Mada University Press; 2013

20. Notoadmodjo S. Metodologi Penelitian Kesehatan. Jakarta: Rineka Cipta; 2012

21. Widoyoko EP. Teknik Penyusunan Instrumen Penelitian. Yogyakarta: Pustaka Pelajar; 2015 
22. Al Rasheed A, Yagoub U, Alkhashan H, Abdelhay O, Alawwad A, Al Aboud A, et al. Prevalence and Predictors of Self-Medication with Antibiotics in $\mathrm{Al}$ Wazarat Health Center, Riyadh City, KSA. Biomed Res Int. 2016;2016:3916874. doi:10.1155/2016/3916874

23. Pavydè E, Veikutis V, Mačiulienè A, Mačiulis V, Petrikonis K, Stankevičius E. Public Knowledge, Beliefs and Behavior on Antibiotic Use and SelfMedication in Lithuania. Int J Environ Res Public Health.

2015;12(6):7002-16. doi:10.3390/ijerph120607002

24. Fernandez BAM. Studi Penggunaan Antibiotik Tanpa Resep di Kabupaten Manggarai dan Manggarai Barat - NTT. Calyptra. 2014;2(2):1-17

25. Fair RJ, Tor Y. Antibiotics and Bacterial Resistance in the 21st Century. Perspect Medicin Chem. 2014;6:2564. doi:10.4137/PMC.S14459

26. Fazio RH. Attitudes as Object-Evaluation Associations of Varying Strength. Soc Cogn. 2007;25(5):603-37. doi:10.1521/soco.2007.25.5.603 